\title{
Mineralogical and thermal characteristics of low-grade Jinlong bauxite sourced from Guangxi Province, China
}

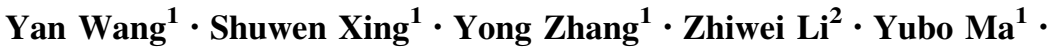 \\ Zengjie Zhang ${ }^{1}$
}

Received: 27 December 2014/ Accepted: 2 May 2015/Published online: 28 May 2015

(c) The Author(s) 2015. This article is published with open access at Springerlink.com

\begin{abstract}
Characteristic samples from the No. 1 ore body of the Jinlong bauxite deposit in Guangxi Province, China, were assessed to determine their chemical composition using whole-rock geochemical analysis, their mineral components using X-ray diffraction, their thermal characteristics via differential thermal analysis, thermogravimetry and differential thermogravimetry, and their dissemination characteristics by scanning electron microscopy/energydispersive spectrometry. The results show that the average $\mathrm{Al}_{2} \mathrm{O}_{3}$ content in the Jinlong bauxite deposit is $41 \%$ and that the $\mathrm{Al}_{2} \mathrm{O}_{3} / \mathrm{SiO}_{2}$ ratio is approximately 2.17 , and thus, the ore may be defined as low-grade bauxite. The main minerals found in the ore were diaspore (20.3-43\%), gibbsite, clays and hematite. In differential thermal analysis results, the bauxite samples exhibit two distinct endothermic peaks, with the dehydration of gibbsite occurring in the $200-260{ }^{\circ} \mathrm{C}$ range and the dehydration of diaspore occurring in the $524-550{ }^{\circ} \mathrm{C}$ range. Thermogravimetry and differential thermogravimetry indicate four decomposition stages: evaporation of adsorbed water $\left(50-160{ }^{\circ} \mathrm{C}\right)$, gibbsite decomposition $\left(190-280^{\circ} \mathrm{C}\right)$,
\end{abstract}

Electronic supplementary material The online version of this article (doi:10.1007/s10973-015-4742-6) contains supplementary material, which is available to authorized users.

Yan Wang

13534687@qq.com; wangyan11@cags.ac.cn

$\triangle$ Yong Zhang

yongzhangcc@163.com

1 MLR Key Laboratory of Metallogeny and Mineral Assessment, Institute of Mineral Resources, CAGS, No. 26 BaiWanZhuang Street, Beijing 100037, China

2 China Coal Geology Engineering Corporation, Beijing 100040, China goethite decomposition $\left(190-280{ }^{\circ} \mathrm{C}\right)$ and diaspore dehydroxylation $\left(460-580{ }^{\circ} \mathrm{C}\right)$. The diaspore belongs to the orthorhombic dipyramidal class and exists primarily in three dissemination forms-euhedral and subhedral grain, bean and oolitic shaped, and aphanitic and microcrystalline aggregates, and is always accompanied by kaolinite and pyrophyllite.

Keywords Jinlong bauxite $\cdot$ XRD $\cdot$ DTA $\cdot$ TG/DTG SEM/EDS

\section{Introduction}

Recently, a large Jinlong bauxite deposit was discovered in Longzhou County, located in western Guangxi Province, China. This deposit, consisting of more than 0.3 billion tons of ore scattered throughout Quaternary laterite, has been explored [1,2], but has only just begun to be exploited. The deposit was originally discovered through an exploration program sponsored by the Ministry of Land and Resources, China.

Mineralogical and geochemical investigations of the bauxite in this region have been performed by several researchers [3-10]. Wei et al. [11] investigated the source materials as well as the formation and evolution processes of two representative bauxite deposits and of terra rossa taken from this region, while Deng et al. [12] demonstrated a genetic relationship between this deposit and the Emeishan plume via $\mathrm{U}-\mathrm{Pb}$ and $\mathrm{Lu}-\mathrm{Hf}$ isotope studies, in which the majority of the zircon $\varepsilon_{\mathrm{Hf}}(\mathrm{T})$ values were in the range of 256-261 Ma and were negative, varying widely from -1.3 to -16.1 . Liu et al. [9] further explored the thermal characteristics of Xinxu bauxite ore from Jingxi County, Guangxi Province, via thermogravimetric/ 
differential thermogravimetric (TG/DTG) analysis, and the resulting curves indicated four decomposition stages: evaporation of adsorbed water, gibbsite decomposition, goethite decomposition and diaspore dehydroxylation [13, 14]. Liu et al. [15] demonstrated that diaspore, hematite and kaolinite are the main mineral components in Dajia Salento-type bauxite, with lesser concentrations of anatase, chamosite, gibbsite, goethite, illite, zircon, quartz and pyrite, and that the diaspore is primarily formed under reducing conditions. The magmatic rocks associated with the Emeishan plume in western Guangxi and the carbonates in the Maokou formation are the main sources of materials for the bauxite formation. Li [16] suggested that variations in the quality of Longzhou bauxite ore were owing to differences in $\mathrm{Al}_{2} \mathrm{O}_{3}$ and $\mathrm{SiO}_{2}$ concentrations. Liang et al. [17] studied the ore-forming geological conditions and features of the source bed, along with the formation lithology and palaeo-structure and topography. Based on an analysis of the regional metallogeny, geological characteristics and mining of the Jinlong bauxite in Longzhou, Deng et al. [1] investigated ore genesis and control factors and also summarized prospecting indications. This research showed that the ore source layer stems from the raw ferrolite mudrock (bauxite) between the Late Devonian and Early Carboniferous discontinuity generated by ancient erosion. He et al. [18] published a short summary of the main features of the bauxite deposits in Guangxi based on a statistical analysis of the amount, type, structure, quality, spatial distribution and use status. The main conclusions of this report were as follows: (1) The large- and medium-scale deposits consist of diaspore karst accumulation-type bauxite deposits, (2) the proportion of bauxite reserves is $94.91 \%$, (3) the ore is of high quality, and (4) highly efficient development and use of the mine are possible. The occurrence of the rare earth element (REE) minerals parisite and churchite in the bauxite deposits was first reported by Wang et al. [13].

In the present study, we conducted a systematic wholerock geochemical analysis based on X-ray diffraction (XRD), differential thermal analysis (DTA) and TG/DTG, simultaneous scanning electron microscopy/energy-dispersive spectrometry (SEM-EDS). These analyses provided further details about the mineralogical and thermal characteristics of typical samples of Jinlong bauxite.

\section{Sampling and methodology}

Based on surface color, texture and structure, five significantly different bauxite samples were collected from the No. 1 ore body (Table 1). Most of the ore body is directly exposed to the surface and presents surface patterns with irregular, striped and equiaxial shapes. Accumulated bauxite ore coexists with the primary ore body, and the two are closely related [19]. The ore body is generally flat, and the occurrence of the ore is associated with the bottom topography, such that it is consistent with the terrain in the area, having a typical slope of $5^{\circ}-15^{\circ}$, increasing to $25^{\circ}-$ $40^{\circ}$ in some regions.

Prior to geochemical analyses, these samples were first crushed to a fine (200 mesh) powder using an agate mill.

The whole-rock abundances of major components of the ore (with the exceptions of $\mathrm{FeO}, \mathrm{H}_{2} \mathrm{O}^{+}$and $\mathrm{CO}_{2}$ ) were determined at the National Research Center for Geoanalysis, China, by X-ray fluorescence (XRF) using a PerkinElmer Optima 8300 spectrometer. The detection limit of this method was $\leq 0.1$ mass $\%$ for each of these major components.

X-ray diffraction analyses were carried out at the MLR Key Laboratory of Metallogeny and Mineral Assessment of Beijing, China, using a Bruker D-8 instrument with $\mathrm{CuK}_{\alpha}$ radiation and the following operating conditions: voltage $=40 \mathrm{kV}$; beam current $=80 \mathrm{~mA}$; graphite monochromator; continuous scanning; scanning speed $=3^{\circ} \mathrm{min}^{-1}$; slit: DS $=\mathrm{SS}=1 \mathrm{~mm}$; ambient temperature $=18^{\circ} \mathrm{C}$ and $30 \%$ humidity.

Simultaneous DTA and TG/DTG measurements were carried out using derivatograph SDTQ $600 \mathrm{~V} 8.0$ with Build 95 software at the Ministry of Education Key Laboratory of Orogenic Belt and Crustal Evolution at Peking University, China. In these trials, pulverized samples of approximately $10 \mathrm{mg}$ were heated from 20 to $800{ }^{\circ} \mathrm{C}$ at $10{ }^{\circ} \mathrm{C} \mathrm{min}^{-1}$ under a $100 \mathrm{~mL} \mathrm{~min}^{-1}$ flow of nitrogen. Using an alumina standard, semiquantitative estimates of aluminum and iron hydroxide in the samples were made based on the TG/DTG results $[2,20]$.

Scanning electron microscopy-energy-dispersive spectrometry was performed at Peking University using an FEI Quanta 200F SEM with the following operating conditions: copper grid, accelerating voltage $=200 \mathrm{~V}-30 \mathrm{kV}$, beam current $>100 \mathrm{nA}$, resolution $\leq 2 \mathrm{~nm}$ at $30 \mathrm{kV}$ in high vacuum mode and $\leq 3.5 \mathrm{~nm}$ at $3 \mathrm{kV}$ in low vacuum mode. The ED $\mathrm{X}$-ray spectrometer analysis range was from ${ }^{5} \mathrm{~B}$ to ${ }^{92} \mathrm{U}$.

Table 1 Characteristics of Jinlong bauxite samples

\begin{tabular}{ll}
\hline Samples & Description \\
\hline ys1 & $\begin{array}{l}\text { Taupe, microcrystalline, sand-clastic texture, massive } \\
\text { structure } \\
\text { Red-brown, crystalline texture, bean-shaped texture, } \\
\text { massive structure }\end{array}$ \\
ys3 & $\begin{array}{l}\text { Purplish brown, aplitic-arenaceous texture, } \\
\text { massive-stylolitic structure }\end{array}$ \\
ys4 & Tan, sand-clastic texture, massive structure \\
ys5 & Purplish brown, oolitic texture, massive structure \\
\hline
\end{tabular}




\section{Ore geochemistry}

The main components of the ores assessed in this study included $\mathrm{Al}_{2} \mathrm{O}_{3}$ (35.25-44.63 mass \%), $\mathrm{Fe}_{2} \mathrm{O}_{3}(12.49-31.53$ mass \%), $\mathrm{SiO}_{2}(7.87-41.97$ mass $\%)$ and $\mathrm{TiO}_{2}(0.99-4.22$ mass \%). The ores exhibited a wide range of compositions (Table 2). On average, the Jinlong bauxite deposit is $41 \% \mathrm{Al}_{2} \mathrm{O}_{3}$, with an $\mathrm{Al}_{2} \mathrm{O}_{3} / \mathrm{SiO}_{2}(\mathrm{~A} / \mathrm{S}$ ) ratio of approximately 2.17 , and thus meets the definition of low-grade bauxite.

\section{Mineral compositions}

Mineralogical analyses demonstrated that diaspore was the primary mineral in the ore (Fig. 1). Pyrophyllite, kaolinite, gibbsite, goethite and hematite occur as minor and accessory fractions, with rutile present as a relict mineral. The diaspore is commonly associated with kaolinite, pyrophyllite and other clay minerals, and is accompanied by hematite in the bauxite deposits.

Semiquantitative XRD results (Table 3) showed that the modal mineral proportions were 20.3-43\% diaspore, 1.6-4.20\% gibbsite, 28.90-52.00\% pyrophyllite, 6.10$33.00 \%$ kaolinite, $1.03-4.21 \%$ goethite and 2.40-12.00\% hematite. These minerals vary widely in their abundance, while the rutile, anatase and magnetite proportions are relatively consistent. The relatively large quantities of silicates decrease the $\mathrm{A} / \mathrm{S}$ ratio and would tend to make mineral separation difficult.

\section{Thermal analysis}

\section{Differential thermal analysis}

Differential thermal analysis is a technique in which the difference in temperature between a sample and reference

Table 2 Major components of Jinlong bauxite samples

\begin{tabular}{lcrrrc}
\hline Samples/mass $\%$ & \multicolumn{1}{c}{ ys1 } & \multicolumn{1}{c}{ ys2 } & \multicolumn{1}{c}{ ys3 } & \multicolumn{1}{c}{ ys4 } & \multicolumn{1}{c}{ ys5 } \\
\hline $\mathrm{SiO}_{2}$ & 28.09 & 7.87 & 23.42 & 33.41 & 41.97 \\
$\mathrm{Al}_{2} \mathrm{O}_{3}$ & 44.63 & 42.18 & 42.27 & 41.71 & 35.25 \\
$\mathrm{CaO}$ & $<0.05$ & $<0.05$ & 0.06 & $<0.05$ & $<0.05$ \\
$\mathrm{Fe}_{2} \mathrm{O}_{3}$ & 15.83 & 31.53 & 21.25 & 13.84 & 12.49 \\
$\mathrm{FeO}$ & 0.38 & 1.94 & 0.79 & 0.29 & 0.36 \\
$\mathrm{MgO}$ & $<0.05$ & 0.32 & 0.17 & $<0.05$ & $<0.05$ \\
$\mathrm{MnO}$ & 0.006 & 0.06 & 0.04 & 0.04 & 0.11 \\
$\mathrm{Na}_{2} \mathrm{O}$ & $<0.05$ & 0.07 & $<0.05$ & $<0.05$ & $<0.05$ \\
$\mathrm{P}_{2} \mathrm{O}_{5}$ & 0.04 & 0.28 & 0.13 & 0.05 & 0.08 \\
$\mathrm{TiO}_{2}$ & 1.85 & 4.22 & 2.47 & 1.52 & 0.99 \\
$\mathrm{LOI}$ & 9.02 & 10.78 & 9.45 & 8.68 & 8.6 \\
\hline
\end{tabular}

material is monitored against time or temperature while the temperature of the sample, in a specified atmosphere, is precisely monitored [21,22]. Although DTA curves can be used to "fingerprint" a mineral phase, this technique is more typically applied to determine transformations in mineral components and crystal structures during heating. The main changes that can be observed include
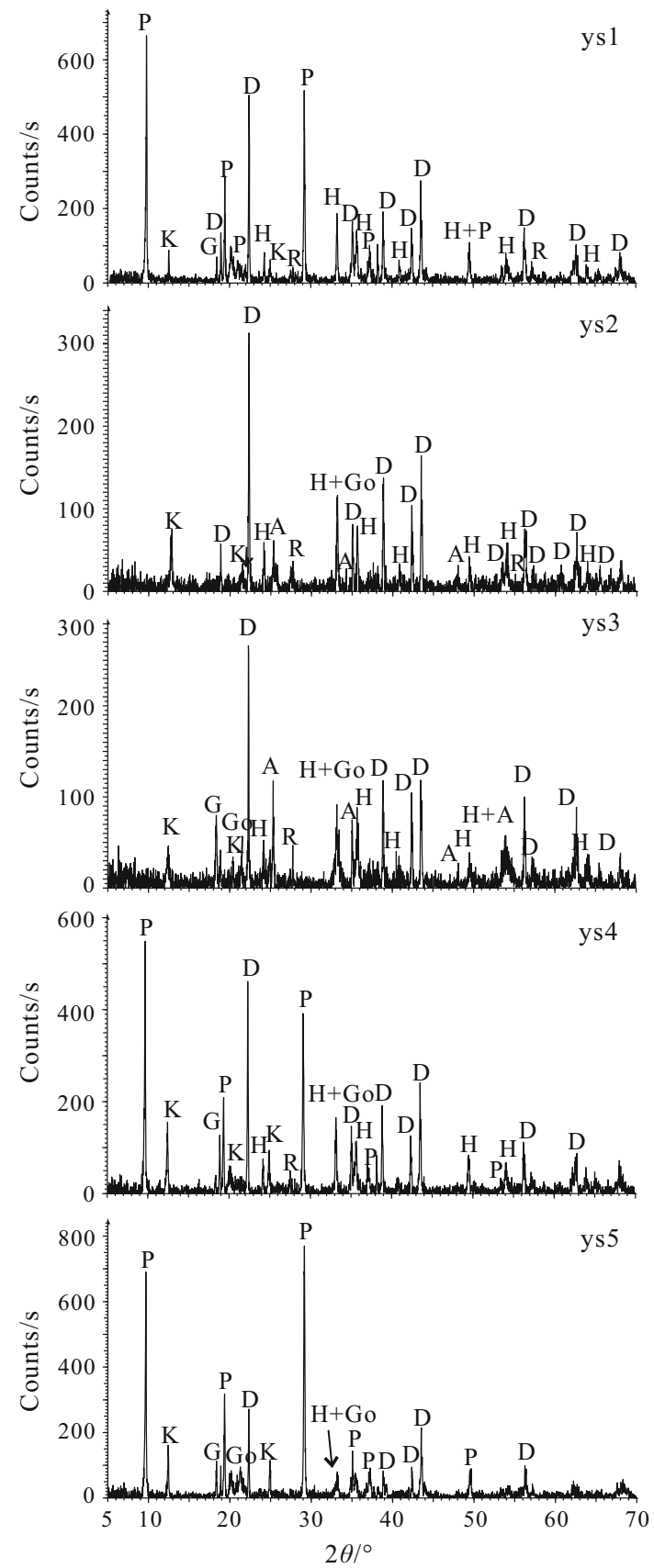

Fig. 1 XRD patterns of typical samples of Jinlong bauxite. D, diaspore, $\mathrm{AlOOH}$; G, gibbsite, $\mathrm{Al}(\mathrm{OH})_{3}$; Go, goethite, $\mathrm{FeOOH} ; \mathrm{H}$, hematite, $\mathrm{Fe}_{2} \mathrm{O}_{3}$; K, kaolinite, $\mathrm{Al}_{4}(\mathrm{OH})_{8}\left(\mathrm{Si}_{4} \mathrm{O}_{10}\right)$; $\mathrm{P}$, pyrophyllite, $\mathrm{Al}_{2} \mathrm{Si}_{4} \mathrm{O}_{10}(\mathrm{OH})_{2} ; \mathrm{A}$, anatase, $\mathrm{TiO}_{2} ; \mathrm{R}$, rutile, $\mathrm{TiO}_{2}$ 
Table 3 Semi-quantitative mineralogical analyses of typical bauxite samples

\begin{tabular}{|c|c|c|c|c|c|c|}
\hline \multirow[t]{2}{*}{ Mineral name } & \multirow[t]{2}{*}{ Formula } & \multicolumn{5}{|c|}{ Content $/ \%$} \\
\hline & & ys1 & ys2 & ys3 & ys4 & ys5 \\
\hline Diaspore & $\mathrm{AlOOH}$ & 36.50 & 43.00 & 36.00 & 24.00 & 20.30 \\
\hline Gibbsite & $\mathrm{Al}(\mathrm{OH})_{3}$ & 3.10 & - & 1.60 & 3.00 & 4.20 \\
\hline Goethite & $\mathrm{FeOOH}$ & - & 4.21 & 1.30 & 2.25 & 2.50 \\
\hline Hematite & $\mathrm{Fe}_{2} \mathrm{O}_{3}$ & 6.90 & 12.00 & 7.00 & 7.00 & 2.40 \\
\hline Kaolinite & $\mathrm{Al}_{4}(\mathrm{OH})_{8}\left(\mathrm{Si}_{4} \mathrm{O}_{10}\right)$ & 6.10 & 33.00 & 17.00 & 19.00 & 13.70 \\
\hline Pyrophyllite & $\mathrm{Al}_{2} \mathrm{Si}_{4} \mathrm{O}_{10}(\mathrm{OH})_{2}$ & 46.70 & - & 28.90 & 44.00 & 52.00 \\
\hline Anatase & $\mathrm{TiO}_{2}$ & - & 5.10 & 6.00 & - & - \\
\hline Rutile & $\mathrm{TiO}_{2}$ & 0.70 & 2.40 & 2.60 & 0.70 & 0.40 \\
\hline
\end{tabular}

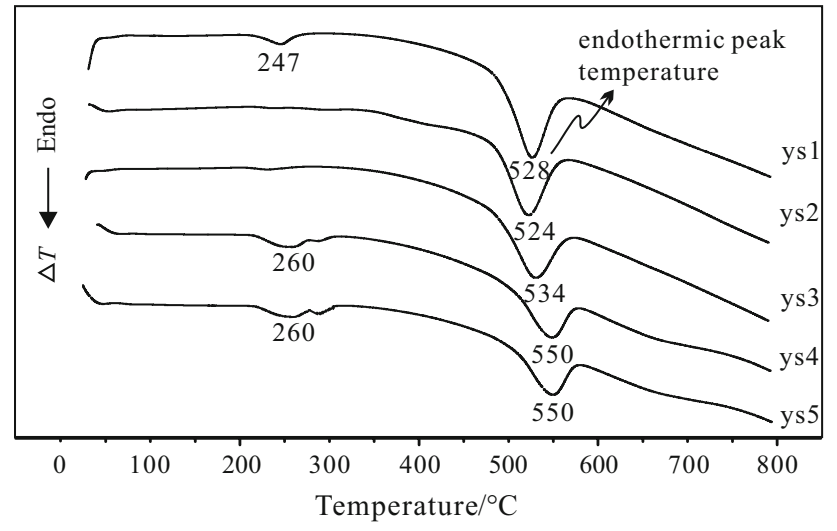

Fig. 2 DTA plots obtained from the Jinlong bauxite samples

dehydration, oxidation of valence-variable elements, recrystallization of amorphous minerals and mineral phase transformations [23, 24]. Each of the bauxite samples generated a similar DTA pattern (Fig. 2). The resulting DTA curves consist of three distinct stages, as follows.

First The first endotherm appears in the $20-100{ }^{\circ} \mathrm{C}$ stage: range [19] without any accompanying mass change and is attributed to a structural rearrangement at the molecular level $[25,26]$

Second A distinct endothermic peak in the stage: $\quad 200-260{ }^{\circ} \mathrm{C}$ range occurs in all samples except ys2 and represents the breakdown from gibbsite to boehmite ( $\gamma$-AlOOH) [27]. Another weak endothermic peak is evident in the $280-300{ }^{\circ} \mathrm{C}$ range for ys 2 , ys 4 and ys 5 and is attributed to the transition from goethite $(\mathrm{FeOOH})$ to hematite $\left(\alpha-\mathrm{Fe}_{2} \mathrm{O}_{3}\right)$ [22, 28-30]. The endothermic peaks associated with gibbsite and goethite were of relatively low intensity and were not obvious in the ore samples
Third All samples display a marked endothermic stage: peak in the $500-600{ }^{\circ} \mathrm{C}$ range, attributed to thermal decomposition resulting in the formation of aluminum oxide and water. Breakdown from boehmite to $\gamma-\mathrm{Al}_{2} \mathrm{O}_{3}[31,32]$ was not observed, likely because the associated peak is weak and was therefore masked by the diaspore endotherm. Dehydroxylation of diaspore to $\alpha-\mathrm{Al}_{2} \mathrm{O}_{3}$ was evident in the 524-550 ${ }^{\circ} \mathrm{C}$ range. This wide temperature range possibly includes the first two endotherms: the formation of boehmite and, at higher temperatures (not observed here), the dehydroxylation of the boehmite formed earlier to $\gamma-\mathrm{Al}_{2} \mathrm{O}_{3}$. Overall, the endothermic peaks of the diaspore in the ore samples were all very similar

The transformations reflected in the DTA curves may be described by the following reactions.

Gibbsite:

$\gamma-\mathrm{Al}(\mathrm{OH})_{3} \stackrel{\text { Endo }\left(200-260^{\circ} \mathrm{C}\right)}{\longrightarrow} \mathrm{AlOOH}+\mathrm{H}_{2} \mathrm{O}$

$2 \gamma-\mathrm{AlOOH} \stackrel{\text { Endo }\left(500-600^{\circ} \mathrm{C}\right)}{\longrightarrow} \gamma-\mathrm{Al}_{2} \mathrm{O}_{3}+\mathrm{H}_{2} \mathrm{O}$

Diaspore:

$2 \alpha-\mathrm{AlOOH} \stackrel{\text { Endo }\left(500-600^{\circ} \mathrm{C}\right)}{\longrightarrow} \alpha-\mathrm{Al}_{2} \mathrm{O}_{3}+\mathrm{H}_{2} \mathrm{O}$

Goethite:

$2 \alpha-\mathrm{FeOOH} \stackrel{\text { Endo }\left(280-300^{\circ} \mathrm{C}\right)}{\longrightarrow} \alpha-\mathrm{Fe}_{2} \mathrm{O}_{3}+\mathrm{H}_{2} \mathrm{O}$

It has been determined that boehmite converts into socalled transition aluminas at $600{ }^{\circ} \mathrm{C}$ and at higher temperatures $\left(1050{ }^{\circ} \mathrm{C}\right)$ converts to alumina $\left(\mathrm{Al}_{2} \mathrm{O}_{3}\right)$ in a corundum structure [19], and that this transformation temperature varies according to the size of the boehmite crystallite [32]. Similarly, pyrophyllite is high-temperature 
refractory, and the DTA curve of pyrophyllite studied by Sanchez-Soto et al. [33] shows a broad endothermic dehydration peak centered at $760{ }^{\circ} \mathrm{C}$ and a shoulder effect at $840^{\circ} \mathrm{C}$, the latter being associated with a residual loss of hydroxyl groups. On further heating, two exothermic DTA effects appear due to pyrophyllite decomposition, centered at 1215 and $1325{ }^{\circ} \mathrm{C}$. Given the restricted temperature range of $20-800{ }^{\circ} \mathrm{C}$ applied in the present study, these transitions cannot be verified in the case of the Jinlong samples.

\section{Thermogravimetry}

Thermogravimetry is a technique that measures mass changes in a sample that result from evaporation, decomposition, oxidation and other effects caused by temperature changes $[4,22]$. The TG curves obtained from the Jinlong samples are shown in Fig. 3 and display two distinct mass loss steps. The overall reaction can be divided into three stages, as follows.

First At approximately $150{ }^{\circ} \mathrm{C}$, the TG curves stage: show a minor loss of absorbed water in each of the samples $(0.1,1.0,0.4,0.3$ and 0.4 mass $\%$ for ys1, ys2, ys3, ys4 and ys5, respectively)

Second All samples except ys2 undergo a more stage: distinct mass loss than in the first stage over the $215-350{ }^{\circ} \mathrm{C}$ range, most likely because of gibbsite and goethite dehydroxylation.

Calculations based on the mass loss suggest that gibbsite and goethite were present in the samples in varying amounts (gibbsite results: ys $1=3.03 \%$, ys $2=$ not detected, ys $3=0.87 \%$, ys $4=3.47 \%$, ys5 $=4.33 \%$; goethite results: ys $1=$ not detected, ys $2=17.80 \%$, ys $3=1.98 \%$, ys4 $=5.93 \%$, ys5 $=4.94 \%$ )

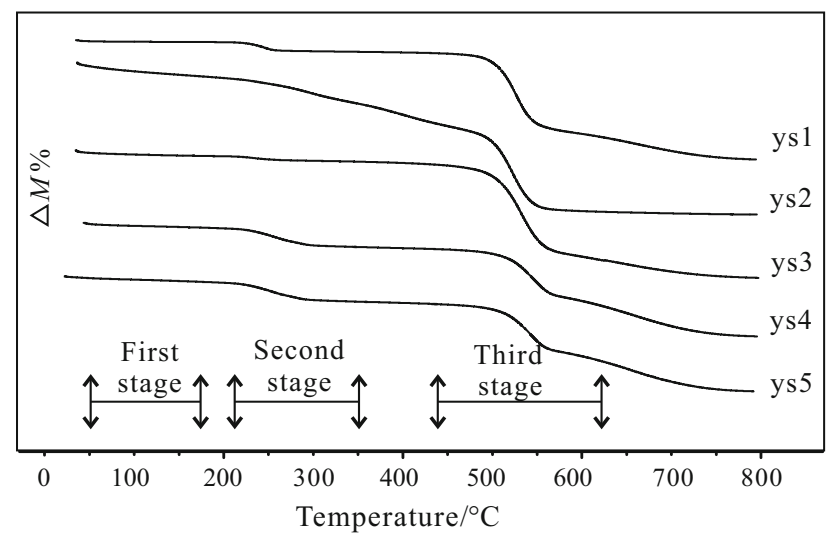

Fig. 3 TG plots obtained from the Jinlong bauxite samples
Third Each sample shows the diaspore stage: dehydroxylation reaction between 420 and $615{ }^{\circ} \mathrm{C}$, with a concomitant calculated mass loss of 3.5-6.9\%. In particular, samples ys2 and ys 3 show a comparatively high mass loss, indicative of relatively high diaspore contents. The diaspore content (in mass \%) of each sample was calculated as ys $1=38.7$, ys $2=41.3$, ys $3=46.0$, ys $4=26.7$ and ys5 $=23.3$

The diaspore, goethite and gibbsite concentrations estimated by XRD roughly agree with these values derived from TG.

\section{Differential thermogravimetry}

Differential thermogravimetry is a method of recording the first-order derivative of TG curves versus temperature or time and thus provide a continuous record of the rate of mass change as a function of temperature or time [34].

Differential thermogravimetry curves can be used to distinguish between the decomposition of gibbsite and goethite, and the associated reactions can be divided into four stages (Fig. 4) as follows.

First Adsorbed water evaporates when the stage: temperature reaches $50-160{ }^{\circ} \mathrm{C}$

Second A distinct endothermic peak occurs between stage: $\quad 190$ and $280^{\circ} \mathrm{C}$ in most samples, except in the case of ys 2 , and represents the transformation of gibbsite to boehmite. The endothermic peaks associated with gibbsite in four of the samples occurred at similar temperatures: ys $1: 243{ }^{\circ} \mathrm{C}$, ys $3: 230{ }^{\circ} \mathrm{C}$, ys4:257 ${ }^{\circ} \mathrm{C}$ and ys5:257 ${ }^{\circ} \mathrm{C}$

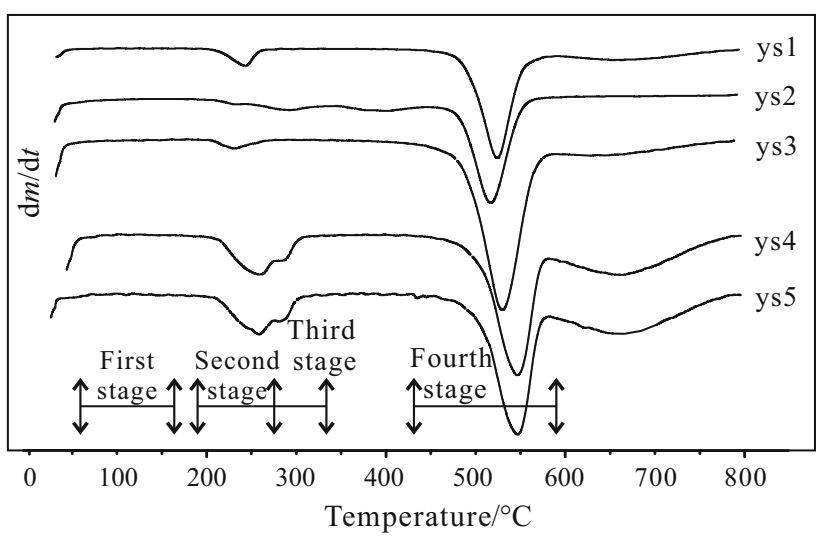

Fig. 4 DTG plots obtained for the Jinlong bauxite samples 

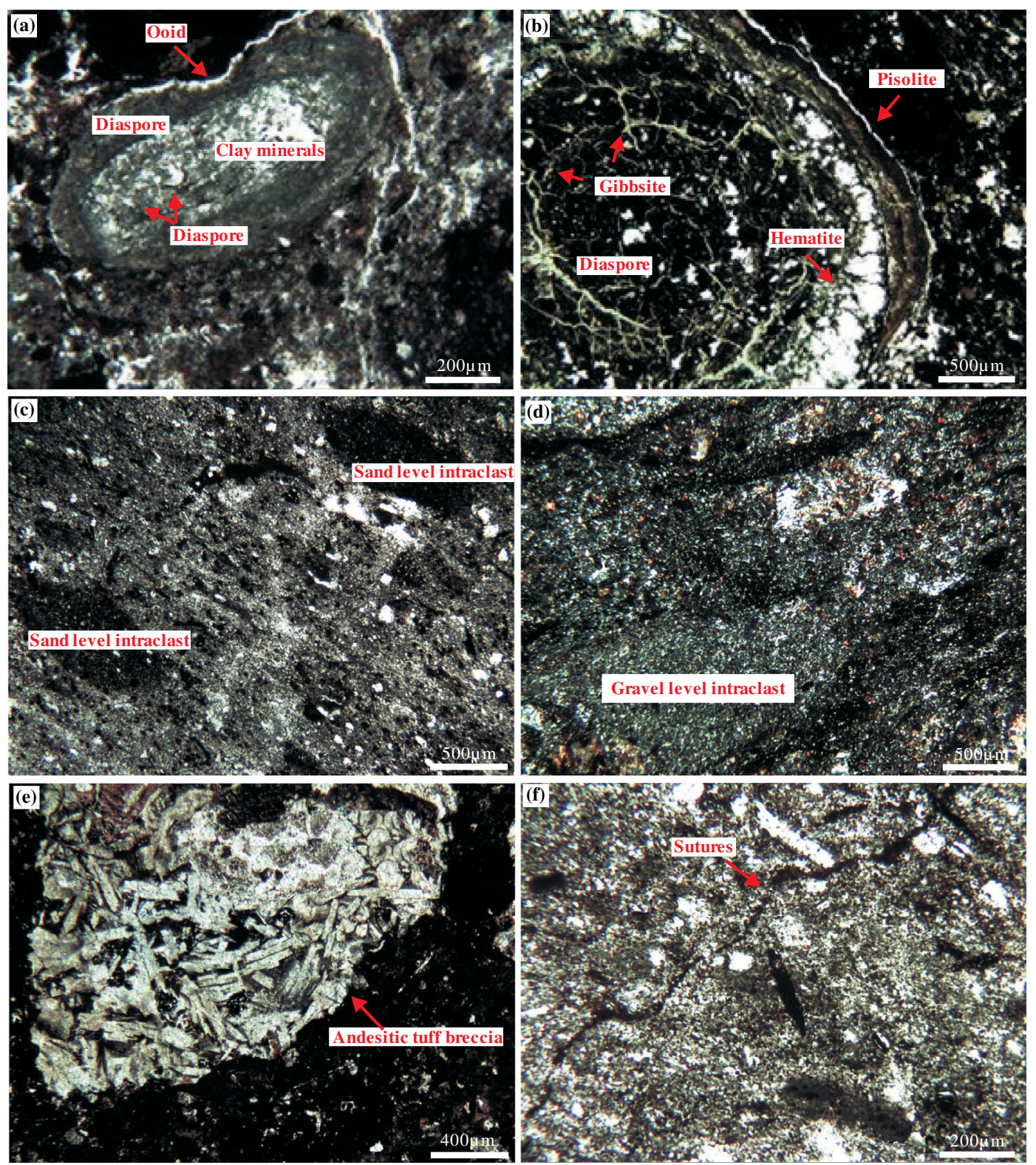

Fig. 5 Microstructures of bauxite ores: a an ooid formed by aggregates of diaspore and clay minerals, $\mathbf{b}$ a bean formed by aggregates of diaspore and clay minerals, filling the void space in the gibbsite, with some hematite and goethite filling in the void spaces within the diaspore aggregates as interstitial structures,

c sand-level debris formed by aggregates of diaspore, gibbsite, hematite and goethite, $\mathbf{d}$ gravel-level debris formed by aggregates of diaspore, gibbsite, hematite and goethite, e andesitic tuff breccia formed by diaspore and $\mathbf{f}$ sutures coexisting primarily with iron 


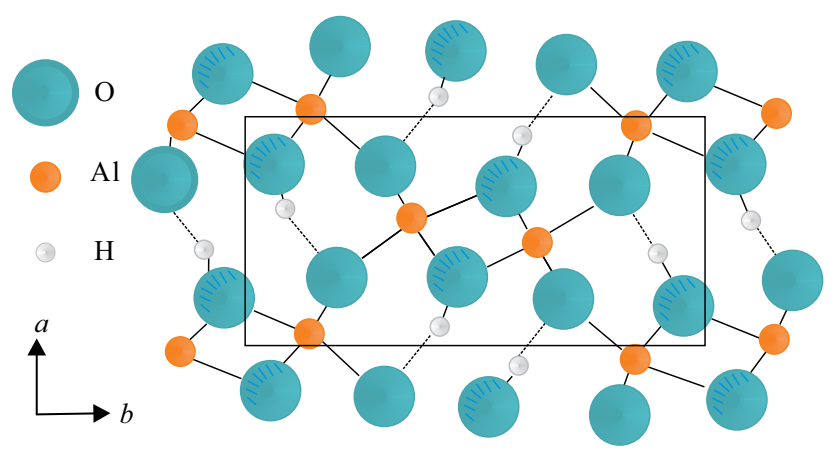

Fig. 6 A projection of diaspore crystal structure on the 001 face [38]
Third A weak endothermic peak in the $280-340{ }^{\circ} \mathrm{C}$ stage: $\quad$ range occurs in the case of ys 2 , ys4 and ys 5 and represents the breakdown of goethite [28, 35]. The exact temperatures observed were as follows: ys 2:295 ${ }^{\circ} \mathrm{C}$, ys4: $290{ }^{\circ} \mathrm{C}$ and ys5:288 ${ }^{\circ} \mathrm{C}$. This same peak was also generated by sample ys 1 and ys 3 but was significantly weaker, indicating lower goethite contents

Fourth A peak in the 460-580 ${ }^{\circ} \mathrm{C}$ range denotes diaspore stage: decomposition. This endothermic peak was recorded as follows: ys 1:524 ${ }^{\circ} \mathrm{C}$, ys $2: 519{ }^{\circ} \mathrm{C}$, ys4:529 ${ }^{\circ} \mathrm{C}$, ys5: $545^{\circ} \mathrm{C}$ and ys5:546 ${ }^{\circ} \mathrm{C}$
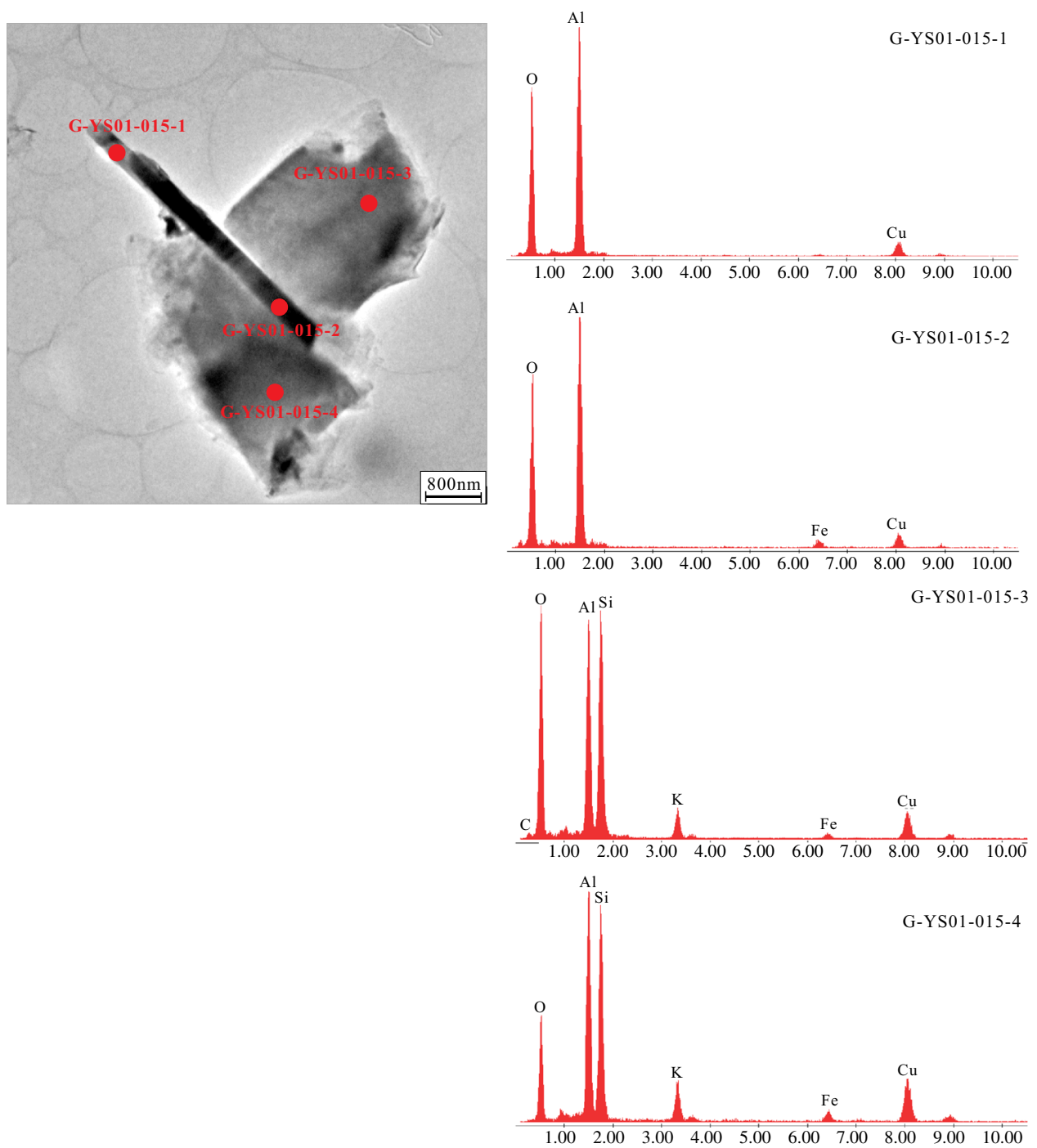

Fig. 7 Backscattered SEM micrograph and energy-dispersive spectra of diaspore in the Jinlong bauxite deposit. Pyrophyllite and kaolinite crystals (a sample G-YS01-015-3/4, b sample G-YS01-016-3/4) fill

the void spaces in the diaspore network, and hematite (a G-YS01015-1/2, b G-YS01-016-1/2) coexists within the clay minerals, in the form of micro-inclusions 


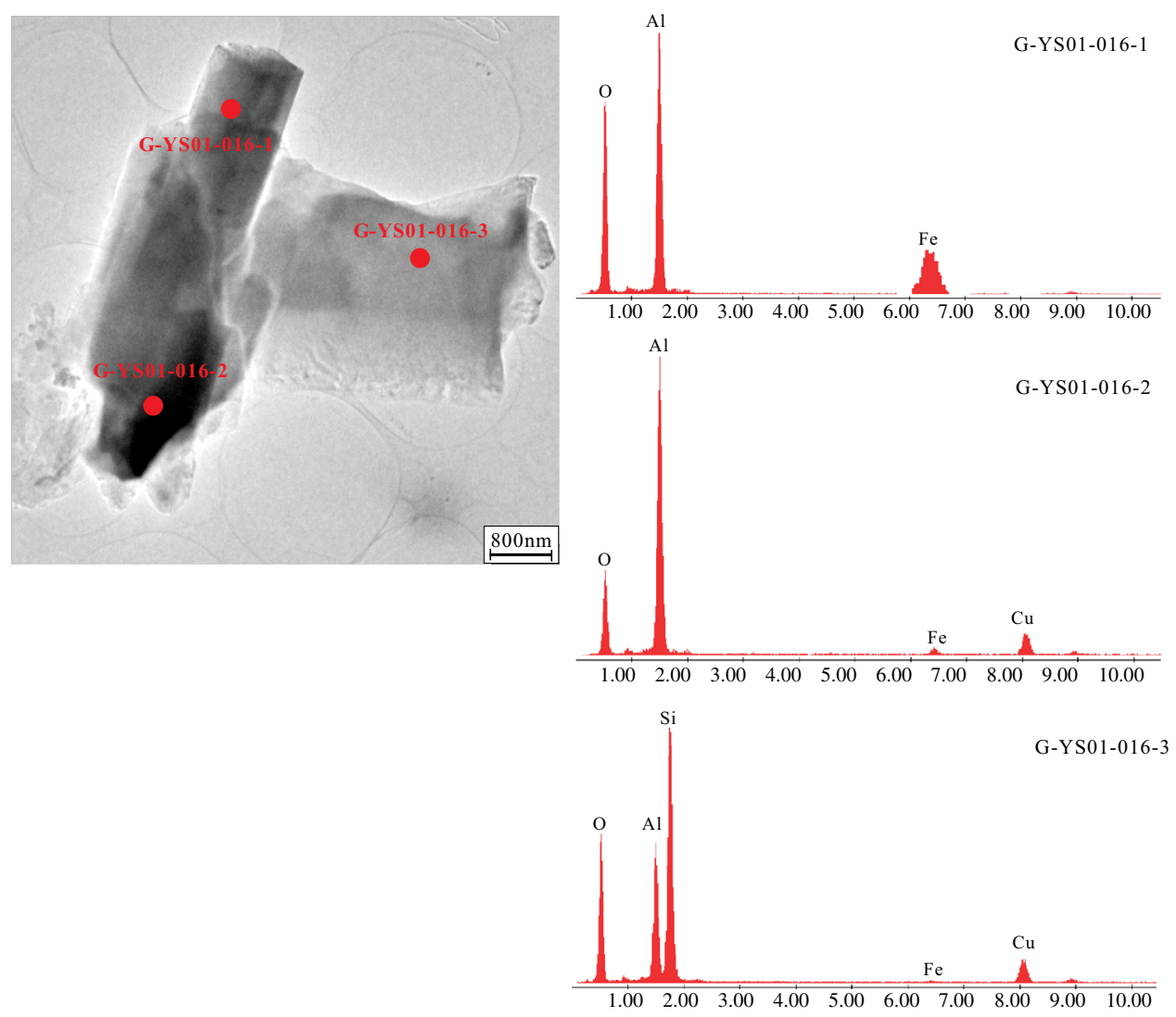

Fig. 7 continued
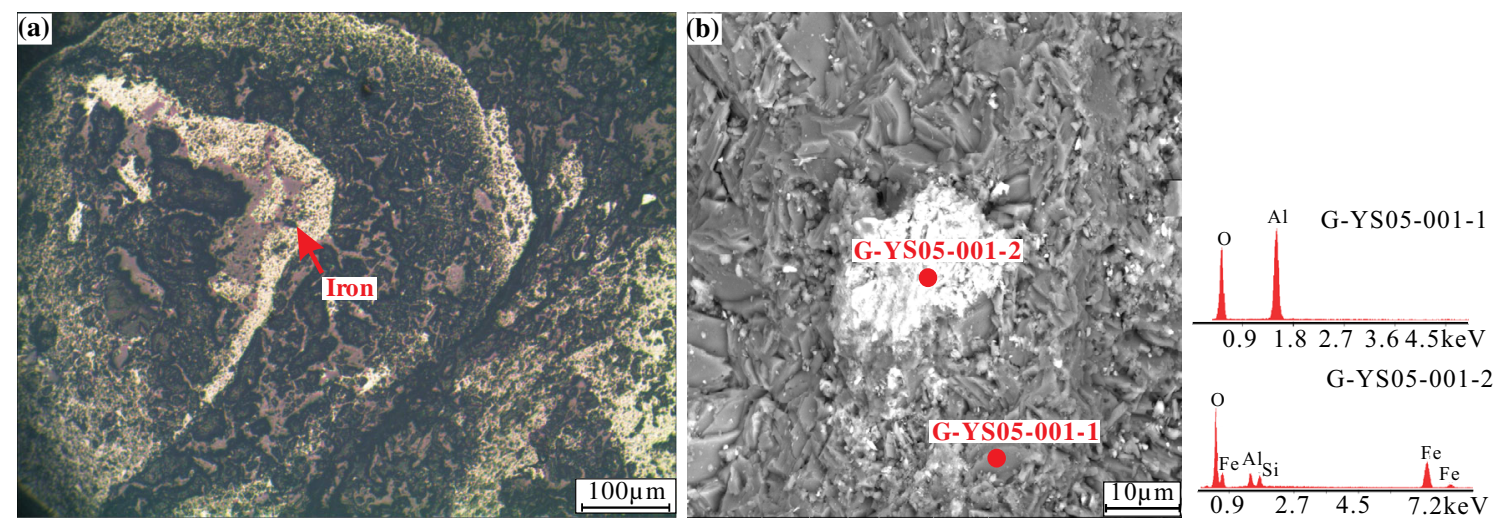

Fig. 8 The distribution of iron in the debris, as shown by an X-ray spectrum and a SEM/EDS image of the Jinlong bauxite deposit

\section{Ore structures}

The Jinlong bauxite deposit occurs in Quaternary laterite and contains karstic-type diaspore. The ore consists primarily of ooids (Fig. 5a), beans (Fig. 5b), sand and gravellevel debris (Fig. 5c, d) and has a metasomatic texture (Fig. 5e) with massive suture structures (Fig. 5f). Diaspore is widely distributed in the beans, ooids and other matrices as cryptocrystalline particles, and clay minerals such as kaolinite and pyrophyllite often coexist with the diaspore. Hematite and goethite are the primary iron oxide and hydroxide in the Jinlong bauxite and occur in void spaces as aggregates, veins or single crystals. These materials may also coexist to some extent with clay minerals, imparting a brown coloration to the rocks.

Ooids (Fig. 5a) and beans (Fig. 5b) formed from aggregates of diaspore and clay minerals were observed, and a scattered, concentric cortex of the diaspore and clay 
minerals fills the void space in the gibbsite, while iron fills in the void spaces within the diaspore aggregates to form interstitial structures.

Sand- and gravel-level debris are formed from aggregates of diaspore, gibbsite and iron. The sand-level debris (Fig. 5c) are characterized by small particle sizes, primarily within the range of $0.2-0.5 \mathrm{~mm}$, although some are in the range of $0.5-1 \mathrm{~mm}$ and still fewer in the range from 1 to $2 \mathrm{~mm}$, with both scattered and directional distributions. The gravel-level debris (Fig. 5d) particles are mainly in the range of $2-3 \mathrm{~mm}$ although some $3-5 \mathrm{~mm}$ particles are also evident, with directional distributions.

Andesitic tuff breccia is also formed by the diaspore (Fig. 5e) mostly within the particle size range of $0.5-1 \mathrm{~mm}$, but with some 1-2 mm particles, with scattered distributions.

Sutures with wave and dentate shapes are also seen, usually together with iron and gibbsite (Fig. 5f).

\section{Dissemination characteristics of diaspore}

The chemical formula of diaspore is $\mathrm{A}_{2} \mathrm{O}_{3} \cdot \mathrm{H}_{2} \mathrm{O}$ or $\alpha$ $\mathrm{AlO}(\mathrm{OH})$, and its ideal composition consists of $\mathrm{Al}_{2} \mathrm{O}_{3}$ $(84.89 \%)$ and $\mathrm{H}_{2} \mathrm{O}(15.02 \%)$. Diaspore has a chain-type structure and belongs to the orthorhombic dipyramidal morphological class (Fig. 6). The crystal structure of diaspore is similar to that of goethite, and it typically occurs as an ultrafine flake or nodular block and is rarely laminated. Its crystal cell parameters have been reported as $a=4.41 \AA, b=9.40 \AA$ and $c=2.84 \AA[36,37]$.

Three main forms of diaspore are found throughout the ore: euhedral to semieuhedral crystalline, pisolitic and ooidal and microcrystalline aggregates. The diaspore is often associated with kaolinite, pyrophyllite and other clay minerals and is accompanied by iron-based minerals. It is widely distributed in ooids, beans and other matrices as cryptocrystalline particles. Backscatter electron (BSE) images (Fig. 7) show that the majority of the clay minerals are dissolved, forming abundant voids with various sizes. Flakes or aggregates of iron-based minerals fill in the void spaces between diaspore aggregates. These results indicate an epigenetic origin for the bauxite, such that some of the diaspore grains coexist with pyrophyllite, kaolinite and other clay minerals [38, 39].

It was not possible to obtain an exact chemical composition of the diaspore, irrespective of the particle size, because compositional data from chemical analysis or $\mathrm{X}$-ray spectra almost always showed evidence of small amounts of $\mathrm{SiO}_{2}, \mathrm{~K}_{2} \mathrm{O}, \mathrm{Fe}_{2} \mathrm{O}_{3}$ and $\mathrm{TiO}_{2}$. These compounds are believed to have come from the surrounding minerals or other minerals adhering to the surface of the diaspore, rather than being present in the mineral itself.

Figure $7 \mathrm{a}, \mathrm{b}$ presents BSE images of bauxite ore samples. Here pyrophyllite and kaolinite crystals fill the void spaces within the diaspore network and banded hematite that coexists with the clay minerals as micro-inclusions.

In these samples, diaspore was found to exist in close proximity to hematite, goethite and other iron-based minerals (Fig. 8a). Hematite and rutile crystals filled the void space in the beans and ooids formed by the diaspore (Fig. 8b), while the iron-based minerals filled both the core and the ring sections.

\section{Conclusions}

1. On average, the Jinlong bauxite deposit contains $41 \%$ $\mathrm{Al}_{2} \mathrm{O}_{3}$, with an $\mathrm{Al}_{2} \mathrm{O}_{3} / \mathrm{SiO}_{2}$ ratio of about 2.17. The ore also contains $\mathrm{Fe}_{2} \mathrm{O}_{3} \quad\left(12.49-31.53\right.$ mass \%), $\mathrm{SiO}_{2}$ (7.87-41.97 mass \%) and $\mathrm{TiO}_{2}(0.99-4.22$ mass \%). Diaspore $(20.3-43 \%)$ is the primary mineral in the samples, with pyrophyllite (28.90-52.00\%), kaolinite (6.10-33.00\%), gibbsite (1.6-4.20\%), hematite (2.40-12.00\%) and goethite (1.03-4.21\%) occurring as minor and accessory phases. This assemblage is typical of bauxite deposits.

2. DTA curves exhibit two endotherms in the $200-260{ }^{\circ} \mathrm{C}$ range resulting from gibbsite and $524-550{ }^{\circ} \mathrm{C}$ range from diaspore. TG curves present two obvious mass loss steps that occur in three stages: adsorbed water is lost $\left(50-150{ }^{\circ} \mathrm{C}\right)$, gibbsite and goethite decompose $\left(215-350{ }^{\circ} \mathrm{C}\right)$, and diaspore decomposes $\left(420-615^{\circ} \mathrm{C}\right)$. DTG curves indicate a four-stage transformation process in which it is possible to distinguish between gibbsite and goethite decomposition. In these stages, adsorbed water is lost $\left(50-160{ }^{\circ} \mathrm{C}\right)$, gibbsite decomposes $\left(190-280{ }^{\circ} \mathrm{C}\right)$, goethite decomposes $\left(280-340{ }^{\circ} \mathrm{C}\right)$, and diaspore decomposes $\left(460-580{ }^{\circ} \mathrm{C}\right)$. Part of ongoing work will increase the heating temperature to $1500^{\circ}$ or higher, to better research pyrophyllite and other minerals thermal decomposition process.

3. The diaspore in this ore has a chain-type structure and belongs to the orthorhombic dipyramidal class. Three forms of diaspore are present: (a) euhedral to semieuhedral crystalline, (b) pisolitic and ooidal and (c) microcrystalline aggregates. Crystals of pyrophyllite and kaolinite fill the void spaces in the diaspore assemblage. Hematite and rutile coexist within the clay minerals, in the form of micro-inclusions. Thus, the characteristic structure of the disseminated diaspore is very complicated.

Acknowledgements This research was jointly supported by the Special Fund of the Chinese Central Government for Basic Scientific Research Operations in Commonwealth Research Institutes (No. K1312) and the Chinese Geological Survey Program (Nos. 1212011220806, 12120114051301, 12120114051401 and 12120114004001). 
Open Access This article is distributed under the terms of the Creative Commons Attribution 4.0 International License (http:// creativecommons.org/licenses/by/4.0/), which permits unrestricted use, distribution, and reproduction in any medium, provided you give appropriate credit to the original author(s) and the source, provide a link to the Creative Commons license, and indicate if changes were made.

\section{References}

1. Deng J. A preliminary study on the geological characteristics and genesis of the Jinlong bauxite ore in Longzhou, Guangxi Province. Miner Res Geol. 2011;25(3):197-202 in Chinese with English abstract.

2. Liu XF, Wang QF, Zhang QZ, Feng YW, Cai SH. Mineralogical characteristics of the superlarge quaternary bauxite deposits in Jingxi and Debao counties, western Guangxi, China. J Asian Earth Sci. 2012;52:53-62. doi:10.1016/j.jseaes.2012.02.011.

3. Guggenheim S, Koster-Van-Groos AF. Baseline studies of the clay minerals society source clays: thermal analysis. Clays Clay Miner. 2001;49(5):433-43.

4. Wang L, Long YZ, Peng SL. Geologic and geochemical study on material derivation of bauxite deposits in western Guangxi. J Guilin Inst Technol. 2004;24(1):1-6 in Chinese with English abstract.

5. Dai TG, Long YZ, Zhang QZ. Rare earth elements investigation of some bauxite in Western Guangxi. Geol Prospect. 2003;39(4):1-5 in Chinese with English abstract.

6. Dai TG, Long YZ, Zhang QZ, Hu B. Geological and geochemical characteristics and metallogenic mechanism of aluminium multimetal deposits in Western Guangxi. J Earth Sci Environ. 2007;29(4):345-50 in Chinese with English abstract.

7. Lv GZ, Zhang TA, Wang XX, Zhang XH, Liu Y, Zhao QY, Do $\mathrm{ZH}$. Effects of intense magnetic field on digestion and settling performances of bauxite. J Cent South Univ. 2014;21(6):2168-75. doi:10.1007/s11771-014-2167-1.

8. Mendelovici E. Acid and thermal treatments of lateritic bauxites. J Therm Anal Calorim. 2004;75:957-64. doi:10.1023/B:JTAN. 0000027189.10320.db.

9. Liu XF, Wang QF, Deng J, Zhang QZ, Zhou F. Thermal analysis of the ore body VII in the Xinxu bauxite deposit, Jingxi County, Guangxi Province. J Mineral Petrol. 2008;28(4):54-8 in Chinese with English abstract.

10. Wang RH, Li M, Meng YJ. Metallogenic characteristics and resource potential estimation of accumulative type bauxite in Guangxi, China. Geol Bull China. 2010;29(10):1526-32 in Chinese with English abstract.

11. Wei X, Ji HB, Li DJ, Zhang FL, Wang SJ. Material source analysis and element geochemical research about two types of representative bauxite deposits and terra rossa in western Guangxi, southern China. J Geochem Explor. 2013;133:68-87. doi:10.1016/j.gexplo.2013.07.010.

12. Deng J, Wang QF, Yang SJ, Liu XF, Zhang QZ, Yang LQ, Yang YH. Genetic relationship between the Emeishan plume and the bauxite deposits in western Guangxi, China: constraints from U$\mathrm{Pb}$ and $\mathrm{Lu}-\mathrm{Hf}$ isotopes of the detrital zircons in bauxite ores. J Asian Earth Sci. 2010;37:412-24. doi:10.1016/j.jseaes.2009.10. 005 .

13. Wang QF, Deng J, Liu XF, Zhang QZ, Sun SL. Discovery of the REE minerals and its geological significance in the Quyang bauxite deposit, west Guangxi, China. J Asian Earth Sci. 2010;39:701-12. doi:10.1016/j.jseaes.2010.05.005.
14. Wang QF, Deng J, Zhang QZ, Liu H, Liu XF, Wan L, Li N, Wang YR, Jiang CZ, Feng YW. Orebody vertical structure and implications for ore-forming processes in the Xinxu bauxite deposit, western Guangxi, China. Ore Geol Rev. 2011;39:230-44. doi:10.1016/j.oregeorev.2011.02.004.

15. Liu XF, Wang QF, Deng J, Zhang QZ, Sun SL, Meng JY. Mineralogical and geochemical investigations of the Dajia Salento-type bauxite deposits, western Guangxi, China. J Geochem Explor. 2010;105:137-52. doi:10.1016/j.gexplo. 2010.04.012.

16. Li YF, Wang MY, Fei YC. Study on process mineralogy of a low-grade bauxite ore in Henan. Nonferr Metal (Miner Process Sect). 2012;2:1-6 in Chinese with English abstract.

17. Liang YP, Deng J, Wu TS, Li SR, Shen YH. Mineralization conditions and metallogenic prediction in Fusui-Longzhou diaspore bauxite. South Land Resour. 2007;10:27-9 in Chinese.

18. He HZ, Yang ZQ, Zheng L. Analysis on the utilization status of Guangxi's bauxite resources and its characteristics. China Min Mag. 2014;23(5):14-22 in Chinese with English abstract.

19. Li HP. Bauxite mineralogy characteristics research. Yunnan Metall. 1997;26(3):61-6 in Chinese.

20. Demir F, Donmez B, Okur H, Sevim E. Calcination kinetic of magnesite from thermogravimetric data. Chem Eng Res Des. 2003;81:618-22.

21. Smothers WJ, Chiang Y. Differential thermal analysis. New York: Chemical Publishing Co Inc.; 1958.

22. Liu XW, Feng YL, Li HR, Zhang P, Wang P. Thermal decomposition kinetics of magnesite from thermogravimetric data. J Therm Anal Calorim. 2012;107:407-12.

23. Popo MI, Edward MD. Differential thermal analysis DTA technology and its application guidance. Beijing: Beijing Norm Univ Press; 1982. p. 1-30 in Chinese.

24. Huang BL. Mineral differential thermal analysis identification manual. Beijing: Science Press; 1987 in Chinese.

25. Frost RL, Ding Z, Ruan HD. Thermal analysis of goethite-relevance to Australian indigenous art. $\mathrm{J}$ Therm Anal Calorim. 2003;71:783-97.

26. Garcia-Guineaa J, Correcher V, Rubioc J. Effects of preheating on diaspore: structure and light emission modifications in colour centres. J Phys Chem Solids. 2005;66:1220-7. doi:10.1016/j.jpcs. 2005.04.001.

27. Bárdossy G, Aleva GJ. Lateritic bauxite: developments in economic geology. Amsterdam: Elsevier. 1990; 27:1-311. ISBN 0-444-98811-4.

28. Todor DN. Thermal analysis of minerals. Kent: Abacus Press; 1976.

29. Walter D, Buxbaum G, Laqua W. The mechanism of the thermal transformation from goethite to hematite. J Therm Anal Calorim. 2001;63:733-48.

30. Gialanella S, Girardi F, Ischia G, Lonardelli I, Mattarelli M, Montagna M. On the goethite to hematite phase transformation. J Therm Anal Calorim. 2010;102:867-73. doi:10.1007/s10973010-0756-2.

31. Smykatz-Kloss W. Differential thermal analysis (minerals and rocks). Berlin: Springer; 1974. p. 11.

32. Laskou M, Margomenou-Leonidopoulou G, Balek V. Thermal characterization of bauxite samples. J Therm Anal Calorim. 2006;84(1):141-5. doi:10.1007/s10973-005-7126-5.

33. Sanchez-Soto PJ, Perez-Rodriguez JL. Thermal analysis of pyrophyllite transformations. Thermochim Acta. 1989;138(2):267-76. doi:10.1016/0040-6031(89)87263-6.

34. Cui HW, Du GB. Form factor analysis of differential thermal analysis curve for organic montmorillionit. J Zhejiang For Coll. 2009;26(5):729-34 in Chinese with English abstract.

35. Li PC. Quality variation analysis in Guangxi Longzhou bauxite. Sci Technol Inf. 2012;13:84-6 in Chinese. 
36. Wang YH, Hu CB, Lan Y. Study on selective flocculation separation of diasporic-bauxite. J China Univ Min Technol. 2006;35(6):742-6 in Chinese with English abstract.

37. Hu YH. Crystal structure of diaspore and kaolinite, pyrophyllite and illite in the flotation separation effect. Met Ore Dress Abroad. 2013;12:24-30 in Chinese with English abstract.

38. Wang Y, Xing SW, Zhang Y, Zhang ZJ, Ma YB, Du XH, Wang $X$. Crystal chemistry and dissemination characteristics of the Jinlong bauxite deposit. J China Univ Min Technol. 2015;2:341-8 in Chinese with English abstract.
39. Wang Y, Xing SW, Zhang Y, Zhang ZJ, Ma YB, Du XH, Wang $\mathrm{X}$. Characteristics of disseminated diaspore in the Longzhou bauxite deposit, Guangxi Province, China. Acta Geol Sin-Engl. 2014;88(s2):1485-6. doi:10.1111/1755-6724.12382_22. 